\title{
PROBLEM BASED LEARNING DALAM MENINGKATKAN KEMAMPUAN MENULIS KARYA ILMIAH MAHASISWA
}

\author{
Kuntum An Nisa \\ Program Studi Pend. Teknologi Informasi STKIP Garut
}

\begin{abstract}
Abstrak --- Masalah pokok dalam tulisan ini difokuskan pada upaya untuk meningkatkan kemampuan menulis mahasiswa dengan metode problem based learning.

Mengingat bahwa untuk menghasilkan sebuah karya ilmiah seperti buku atau jurnal memerlukan sebuah proses panjang seperti menggali ide, menemukan referensi, melakukan penelitian atau menganalisa, maka hambatan dan permasalahan sering tidak terhindarkan.
\end{abstract}

Pembelajaran berdasarkan masalah merupakan pendekatan yang efektif untuk pengajaran proses berfikir tingkat tinggi. Pembelajaran ini membantu peserta didik untuk memproses informasi yang sudah jadi dalam benaknya dan menyusun pengetahuan mereka sendiri tentang dunia sosial dan sekitarnya. Pembelajaran ini cocok untuk mengembangkan pengetahuan dasar maupun kompleks.

Tujuan dari pembelajaran berbasis masalah dikembangkan untuk membantu peserta didik mengembangkan kemampuan berpikir, mengembangkan kemampuan memecahan masalah, keterampilan intelektual, dan menjadi peserta didik yang mandiri. Metode pembelajaran berbasis masalah terdiri atas 8 tahap yaitu menemukan masalah, mendefinisikan masalah, mengumpulkan fakta, menyusun hipotesis,melakukan penyelidikan, menyempurnakan permasalahan yang telah didefinisikan, menyimpulkan alternatif pemecahan masalah secara kolaboratif, dan melakukan pengujian hasil (solusi) pemecahan masalah.

Berbagai problematika yang menjadi kendala mahasiswa dalam menulis karya ilmiah adalah (a) tidak berbakat, (b) kurangnya motivasi dan tidak percaya diri, (c) tidak fokus / kesulitan untuk memulai, (d) wawasan yang sempit, (e) kendala kebahasaan, (f) faktor eksternal dari mahasiswa.

Untuk memecahkan persoalannya seyogianya diarahkan kepada upaya peningkatan kemampuan menulis dan kualitas karya tulis ilmiah, yaitu : (a) perlu dibentuk tim pembimbing, (b) perlu dibentuk forum pengkajian karya tulis ilmiah mahasiswa di setiap perguruan tinggi, (c) perlu dilakukan presentasi terlebih dahulu, (d) perlu diintensifkan lomba karya tulis ilmiah untuk mahasiswa, (e) perlu dilakukan workshop, (f) perlu dilakukan pembenahan dan penyempurnaan sarana sumber informasi untuk mahasiswa.

Kata Kunci : Metode Pembelajaran, Problem Based Learning, Karya Tulis Ilmiah

\section{PENDAHULUAN}

Pendidikan menjadi salah satu faktor penentu kemajuan bangsa. Sayangnya, pendidikan di Indonesia masih belum merata dan membutuhkan peningkatan kualitas. pendidikan mempunyai tugas menyiapkan sumber daya manusia untuk pembangunan. Derap langkah pembangunan selalu diupayakan seirama dengan tuntutan zaman.
Menghadapi Masyarakat Ekonomi ASEAN (MEA) 2015, motivator dan trainer pendidikan, Namin AB Ibnu Solihin menyebutkan, setidaknya ada empat permasalahan pendidikan yang masih dihadapi di Indonesia.

Masalah pertama adalah kurikulum. Sebenarnya pergantian kurikulum itu perlu karena merupakan inovasi dari kurikulum sebelumnya. Permasalahan berikutnya, yakni mahasiswa. Mahasiswa merupakan ujung tombak pendidikan. Tetapi, saat ini mahasiswa minim mendapatkan pelatihan yang aplikatif dan berkualitas. Ketiga, budaya literasi di kalangan mahasiswa masih sangat lemah. Sedangkan permasalahan keempat buku teks pelajaran yang digunakan masih lower order thinking skill (LOTS).

Lingkungan akademis sebagai bagian dari masyarakat seharusnya merupakan area yang paling banyak melahirkan karya tulis ilmiah. Karya tulis ilmiah tersebut diharapkan dapat memberikan manfaat dan kontribusi yang sangat besar bagi masyarakat karena akan menjadi sumber. pengembangan ilmu pengetahuan di segala bidang. Karya ilmiah akan memeberikan manfaat langsung bagi penulisnya tidak hanya dari segi finansial namun lebih dari pada itu akan mengasah kecerdasan berpikir dan sekaligus menambah wawasan ilmu pengetahuan penulis. Akhadiah, Arsjad, dan Ridwan1 mengatakan bahwa menulis akan membawa seseorang untuk mengenali diri, memperluas cakrawala, mendorong seseorang berpikir dan berbahasa secara tertib. Tidak hanya itu, menulis karya ilmiah seperti buku, jurnal artikel ilmiah sebagai suatu karya terpercaya karena melalui prosedur ilmiah akan memberikan manfaat langsung bagi pengembangan ilmu pengetahuan dimana karya tulis tersebut berisi informasi, ide kreatif dan ilmu pengetahuan baru bagi masyarakat.

Dalam hal ini mahasiswa sebagai bagian dari lingkungan akademis tersebut sudah diharapkan untuk melakukan kegiatan menulis secara rutin sehingga dapat melahirkan karya tulis baik karya tulis ilmiah seperti buku, jurnal dan lain-lain maupun karya tulis ilmiah populer seperti artikel. Tulisan - tulisan yang berisi informasi pengetahuan tersebut akan lebih cepat diterima oleh masyarakat dibandingkan dengan hanya berbicara.

Namun kenyataannya seperti halnya dengan membaca, kegiatan menulis dikalangan mahasiswa Indonesia belum membudaya. Hal tersebut nampak pada kecenderungan mereka dimana mereka lebih senang berbicara daripada menulis. Sekarang ini ada banyak yang lahir orator handal, pembicara dan motivator ulung namun tidak mampu menghasilkan karya tulis sehebat apa yang dibicarakan. Ide-ide brilliant tersebut hanya mampu diungkapkan secara lisan namun tidak dalam tulisan. Akibatnya, ketenarannya dalam berbicara tidak mampu 
bertahan dalam waktu lama. Pergeseran waktu akan meneggelamkan kepopuleran mereka dan digantikan dengan pembicara lainnya. Sebaliknya, justru ada orang yang berasal dari kalangan biasa-biasa saja dan bahkan jarang tampil sebagai pembicara kemudian menjadi populer setelah masyarakat membaca tulisannya. Tulisan ilmiah yang dihasilkan oleh seseorang menjadi pengikat ide, gagasan, dan kreatifitas yang dimiliki oleh penulis. Sayangnya, aktifitas menulis yang tentu saja harus dibarengi dengan kebiasaan membaca telah menjadi momok yang menakutkan bagi mahasiswa. Tugas-tugas yang berkaitan dengan kegiatan menulis ilmiah seolah menjadi beban yang sulit terselesaikan dengan baik. Hal tersebut dapat terlihat pada beberapa hal berikut:

1) Rendahnya antusias mahasiswa dalam mengikuti lomba penulisan karya ilmiah atau workshop penulisan karya ilmiah yang dilaksanakan oleh brokrasi baik pemerinta maupun swasta.

2) Kurangnya jumlah tulisan karya ilmiah seperti buku jurnal atau artikel yang dipubilkasikan oleh mahasiswa.

3) Kurangnya pemanfaatan perpustakaan sebagai sumber inspirasi.

4) Mahasiswa lebih senang mendapatkan tugas diskusi daripada tugas menulis laporan tertulis.

5) Mahasiswa lebih senang menyampaikan aspirasi melalui orasi daripada mengungkapkan fenomena atau fakta tersebut ke dalam tulisan ilmiah seperti artikel.

6) Tulisan-tulisan mahasiswa cenderung tidak produktif dan hanya berisi tempelan-tempelan teori yang kadang tidak relevan dengan topik yang sedang dibahas. Bahkan lebih parahnya lagi, tulisan-tulisan tersebut terkadang hanya berisi ciplakan ide atau pemikiran ataupun bahkan tulisan orang lain.

Meskipun demikian tidak dapat dipungkiri bahwa kegiatan menulis ilmiah bukanlah suatu aktifitas yang dapat dilakukan secara spontanitas. Seorang penulis sekurang-kurangnya harus memahami dengan jelas apa yang disebut dengan tulisan ilmiah dan segala bentuk kaidah penulisannya. Selain itu, kegiatan menulis memerlukan banyak latihan, dilakukan berulang-ulang secara berkesinambungan sehingga menghasilkan suatu karya ilmiah yang layak dipublikasikan.

Berbagai alasan dan hambatan yang berbeda-beda dikemukakan oleh mahasiswa sehingga tidak melakukan aktivitas menulis. Tidak berbakat, kurang motivasi, tidak ada waktu, kurangnya referensi adalah bagian dari alasan tersebut. Sebagai contoh, seorang mahasiswa yang mendapat tugas dari dosen untuk menulis makalah sederhana dengan satu topik tertentu lebih sering tidak dapat menyelesaikan tepat waktu dengan alasan belum dapat referensi, tidak tahu mulai dari mana, tidak ada waktu dan sebagainya. Ironisnya terkadang mahasiswa masih bertanya apa sebenarnya yang dimaksud dengan karya ilmiah.

\section{BATASAN DAN RUMUSAN MASALAH}

Masalah pokok dalam tulisan ini difokuskan pada upaya untuk meningkatkan kemampuan menulis mahasiswa dengan metode problem based learning.

\footnotetext{
${ }^{1}$ Direktorat Jenderal Pendidikan Tinggi, Presentasi Sosialisasi Kebijakan Publikasi IImiah Pada Mahasiswa
}

Mengingat bahwa untuk menghasilkan sebuah karya ilmiah seperti buku atau jurnal memerlukan sebuah proses panjang seperti menggali ide, menemukan referensi, melakukan penelitian atau menganalisa, maka hambatan dan permasalahan sering tidak terhindarkan. Permasalahan yang dimaksudkan bukan kesalahan dalam hal penulisan, kesalahan dalam menempatkan kalimat dan sebagainya tetapi permasalahan yang dimaksudkan lebih pada permasalahan yang bersifat psikologis (kesiapan secara fisik dan mental), permasalahan bersifat ekstrinsik dan juga instrinsik mahasiswa untuk menghasilkan sebuah karya ilmiah

Dengan adanya berbagai macam permasalahan yang dihadapi oleh mahasiswa maka tidak mengherankan jika karya tulis yang dihasilkan mahasiswa Indonesia jauh lebih sedikit dibandingkan dengan karya tulis yang dihasilkan mahasiswa dari negara-negara lain. Sebagai contoh, jumlah karya tulis dari Permahasiswaan Tinggi Indonesia hanya sepertujuhnya dari Malaysia $^{1}$

Adapun rumusan masalah sebagai berikut :

1. Apa yang dimaksud dengan problem based learning

2. Bagaimana problematika mahasiswa dalam menulis karya ilmiah

3. Bagaimana meningkatkan kemampuan menulis karya ilmiah mahasiswa dengan problem based learning

\section{PEMBAHASAN}

A. Problem Based Learning

Pengajaran berdasarkan masalah ini telah dikenal sejak zaman John Dewey. Menurut Dewey (dalam Trianto, 2009:91) belajar berdasarkan masalah adalah interaksi antara stimulus dan respon, merupakan hubungan antara dua arah belajar dan lingkungan. Lingkungan memberikan masukan kepada peserta didik berupa bantuan dan masalah, sedangkan sistem saraf otak berfungsi menafsirkan bantuan itu secara efektif sehingga masalah yang dihadapi dapat diselidiki, dinilai, dianalisis, serta dicari pemecahannya dengan baik. Pembelajaran Berbasis Masalah yang berasal dari bahasa Inggris Problem-based Learning adalah suatu pendekatan pembelajaran yang dimulai dengan menyelesaikan suatu masalah, tetapi untuk menyelesaikan masalah itu peserta didik memerlukan pengetahuan baru untuk dapat menyelesaikannya. Pendekatan pembelajaran berbasis masalah (problem-based learning ( PBL) adalah konsep pembelajaran yang membantu mahasiswa menciptakan lingkungan pembelajaran yang dimulai dengan masalah yang penting dan relevan (bersangkut-paut) bagi peserta didik, dan memungkinkan peserta didik memperoleh pengalaman belajar yang lebih realistik (nyata).

Pembelajaran Berbasis Masalah melibatkan peserta didik dalam proses pembelajaran yang aktif, kolaboratif, berpusat kepada peserta didik, yang mengembangkan kemampuan pemecahan masalah dan kemampuan belajar mandiri yang diperlukan untuk menghadapi tantangan dalam kehidupan dan karier, dalam lingkungan yang bertambah kompleks sekarang ini. Pembelajaran Berbasis Masalah dapat pula dimulai dengan melakukan kerja kelompok antar peserta didik. peserta didik menyelidiki sendiri, menemukan permasalahan, kemudian

dari www.dikti.go.id 
menyelesaikan masalahnya di bawah petunjuk fasilitator (mahasiswa).

Pembelajaran Berbasis Masalah menyarankan kepada peserta didik untuk mencari atau menentukan sumber-sumber pengetahuan yang relevan. Pembelajaran berbasis masalah memberikan tantangan kepada peserta didik untuk belajar sendiri. Dalam hal ini, peserta didik lebih diajak untuk membentuk suatu pengetahuan dengan sedikit bimbingan atau arahan mahasiswa sementara pada pembelajaran tradisional, peserta didik lebih diperlakukan sebagai penerima pengetahuan yang diberikan secara terstruktur oleh seorang mahasiswa. Pembelajaran berbasis masalah (Problem-based learning), selanjutnya disingkat PBL, merupakan salah satu model pembelajaran inovatif yang dapat memberikan kondisi belajar aktif kepada peserta didik. PBL adalah suatu model pembelajaran vang, melibatkanpeserta didik untuk memecahkan suatu masalah melalui tahap-tahap metode ilmiah sehingga peserta didik dapat mempelajari pengetahuan yang berhubungan dengan masalah tersebut dan sekaligus memiliki ketrampilan untuk memecahkan masalah. Untuk mencapai hasil pembelajaran secara optimal, pembelajaran dengan pendekatan Pembelajaran Berbasis Masalah perlu dirancang dengan baik mulai dari penyiapan masalah yang yang sesuai dengan kurikulum yang akan dikembangkan di kelas, memunculkan masalah dari peserta didik, peralatan yang mungkin diperlukan, dan penilaian yang digunakan. Pengajar yang menerapkan pendekatan ini harus mengembangkan diri melalui pengalaman mengelola di kelasnya, melalui pendidikan pelatihan atau pendidikan formal yang berkelanjutan.

Oleh karena itu, pembelajaran berdasarkan masalah merupakan pendekatan yang efektif untuk pengajaran proses berfikir tingkat tinggi. Pembelajaran ini membantu peserta didik untuk memproses informasi yang sudah jadi dalam benaknya dan menyusun pengetahuan mereka sendiri tentang dunia sosial dan sekitarnya. Pembelajaran ini cocok untuk mengembangkan pengetahuan dasar maupun kompleks

\section{Konsep Dasar}

Model pembelajaran berbasis masalah adalah pembelajaran yang menekankan pada proses penyelesaian masalah. Dalam implementasi model pembelajaran berbasis masalah, mahasiswa perlu memilih bahan pelajaran yang memiliki permasalahan yang dapat dipecahkan. Model pembelajaran berbasis masalah ini dapat diterapkan dalam kelas jika :

a. Mahasiswa bertujuan agar peserta didik tidak hanya mengetahui dan hafal materi pelajaran saja, tetapi juga mengerti dan memahaminya.

b. Mahasiswa mengiginkan agar peserta didik memecahkan masalah dan membuat kemampuan intelektual peserta didik bertambah.

c. Mahasiswa menginginkan agar peserta didik dapat bertanggung jawab dalam belajarnya.

d. Mahasiswa menginginkan agar peserta didik dapat menghubungkan antara teori yang dipelajari di dalam kelas dan kenyataan yang dihadapinya di luar kelas.

\footnotetext{
${ }^{2}$ Wina Sanjaya, Strategi Pembelajaran (Jakarta: Prenada

Media Group, 2006), h 212-213
}

e. Mahasiswa bermaksud mengembangkan kemampuan peserta didik dalam menganalisis situasi, menerapkan pengetahuan, mengenal antara fakta dan pendapat, serta mengembangkan kemampuan dalam membuat tugas secara objektif.

\section{Ciri dan Karakteristik Pembelajaran Berbasis} Masalah

Pembelajaran berbasis masalah dapat diartikan sebagai rangkaian aktivitas pembelajaran yang menekankan kepada proses penyelesaian masalah yang dihadapi secara ilmiah. Terdapat tiga ciri utama dari pembelajaran berbasis masalah: Pertama, pembelajaran berbasis masalah merupakan aktivitas pembelajaran, artinya dalam implementasinya pembelajaran berbasis masalah adalah sejumlah kegiatan yang harus dilakukan peserta didik. Pembelajaran berbasis masalah tidak mengharapkan peserta didik hanya sekedar mendengarkan, mencatat, kemudian menghafal materi pelajaran, akan tetapi melalui pembelajaran berbasis masalah peserta didik aktif berpikir, berkomunikasi, mencari dan mengolah data, dan akirnya menyimpulkan. Kedua, aktivitas pembelajaran diarahkan untuk menyelesakan masalah. pembelajaran berbasis masalah menempatkan masalah sebagai kata kunci dari proses pembelajaran. Ketiga, pemecahan masalah dilaukan dengan mengunaan pendekatan berpikir secara ilmiah. Berpikir dengan mengunakan metode ilmiah adalah proses berpikir deduktif dan induktif. Proses berpikir ini dilakukan secara sistematis dan empiris. Sistematis artinya berpikir ilmiah dilakukan melalui tahapan-tahapan tertentu, sedangkan empiris artinya proses penyelesaian masalah didasarkan pada data dan fakta yang jelas ${ }^{2}$.

Ada beberapa karakteristik pembelajaran berbasis masalah, Arends (1997) mengidentifikasikan 5 karakteristik sebagai berikut :

a. Pengajuan Pertanyaan atau Masalah

b. Keterkaitan dengan disiplin ilmu lain

c. Menyelidiki masalah autentik

d. Memamerkan hasil kerja

e. Kolaborasi

3. Tujuan Pembelajaran Berbasis Masalah

Pembelajaran berbasis masalah tidak dirancang untuk membantu mahasiswa memberikan informasi sebanyakbanyaknya kepada peserta didik seperti pada pembelajaran langsung dan ceramah, tetapi pembelajaran berbasis masalah dikembangkan untuk membantu peserta didik mengembangkan kemampuan berpikir, mengembangkan kemampuan memecahan masalah, keterampilan intelektual, dan menjadi peserta didik yang mandiri ${ }^{3}$.

\section{Tahapan-Tahapan Pembelajaran Berbasis Masalah}

David Johnson \& Johnson mengemukakan ada lima langkah pembelajaran berbasis masalah melalui kegiatan kelompok yaitu:

a. Mendefinisikan masalah atau merumuskan masalah dari peristiwa tertentu yang mengandung isu konflik, hingga peserta didik menjadi jelas masalah apa yang akan dikaji. Dalam kegiatan ini mahasiswa bisa meminta pendapat dan

\footnotetext{
${ }^{3} \mathrm{H}$. Muslimin Ibrahim, Pembelajaran Kooperatif (Surabaya : UNESAUNIVERSITY, 2000), h 7.
} 
penjelasan peserta didik tentang isu-isu hangat yang menarik untuk dipecahkan.

b. Mendiagnosis masalah, yaitu menentukan sebab-sebab terjadinya masalah, serta menganalisis berbagai faktor yang dapat mendukung dan dalam penyelesaian masalah. Kegiatan ini bisa dilakukan dalam diskusi kelompok kecil, hingga pada akirnya peserta didik dapat menmahasiswatkan tindakan-tindakan prioritas yang dapat dilakukan sesuai dengan jenis penghambat yang diperkirakan.

c. Merumuskan alternatif strategi, yaitu menguji setiap tindakan yang telah dirumuskan melalui diskusi kelas. Pada taapan ini setiap peserta didik didorong untuk berpikir mengemukakan pendapat dan argumentasi tentang kemungkinan setiap tindakan yang dapat dilakukan.

d. Menentukan dan menerapkan srategi pilihan, yaitu pengambilan keputusan tentang strategi mana yang dapat dilakukan.

e. Melakukan evaluasi, baik evaluasi proses maupun evaluasi hasil. Evaluasi proses adalah evaluasi terhadap seluruh kegiatan pelaksanaan kegiatan, sedangkan evaluasi hasil adalah evaluasi terhadap akibat dari penerapan strategi yang diterapkan ${ }^{4}$

\section{Pengelolaan Pembelajaran Berbasis Masalah}

Menurut Arends (1997 : 161), pengelolaan pembelajaran berbasis terdapat 5 langkah utama. Berikut kelima langkah tersebut ${ }^{5}$

\section{a. Mengorientasikan peserta didik pada masalah}

Peserta didik Peserta didik perlu memahami bahwa tujuan pembelajaran berbasis masalah adalah bukan untuk memperoleh informasi baru dalam jumlah besar, tetapi untuk melakukan penyelidikan terhadap masalahmasalah penting dan menjadi peserta didik yang mandiri. Cara yang baik dalam menyajikan masalah untuk suatu materi pelajaran dalam pembelajaran berbasis masalah ini adalah dengan menggunakan kejadian yang mencengangkan dan menimbulkan misteri sihingga membangkitkan minat dan keinginan untuk menyelesaikan masalah yang dihadapi.

b. Mengorganisasikan peserta didik untuk belajar

Pada model pembelajaran berbasis masalah dibutuhkan pengembangan keterampilan kerjasama di antara peserta didik dan saling membantu untuk menyelidiki masalah secara bersama. Berkenaan dengan hal tersebut peserta didik memerlukan bantuan mahasiswa untuk merencanakan penyelidikan dan tugas-tugas pelaporan. Pengorganisian peserta didik kedalam kelompok belajar pada pembelajaran berbasis masalah bisa menggunakan metode kooperatif learning.

c. Mamandu menyelidiki secara mandiri atau kelompok

1. Mahasiswa membantu peserta didik dalam pengumpulan informasi dari berbagai sumber,

\footnotetext{
${ }^{4}$ Wina Sanjaya,Op.cit, h. 215-218

${ }^{5}$ Mustaji, Pengembangan Model Pembelajaran Berbasis Masalah dengan Pola Kolaborasi dalam Mata Kuliah Masalah Sosial. Disertasi. Malang: Program Pascasarjana UIniversitas Negeri Malang, 2009, h 76.
}

peserta didik diberi pertanyaan yang membuat mereka berfikir tentang suatu masalah dan jenis informasi yang diperlukan untuk memecahkan masalah tersebut. Peserta didik diajarkan untuk menjadi penyelidik yang aktif dan dapat menggunakan metode yang sesuai untuk masalah yang dihadapinya, peserta didik juga perlu diajarkan apa dan bagaimana etika penyelidikan yang benar.

2. Mahasiswa mendorong pertukaran ide dan gagasan secara bebas. Penerimaan sepenuhnya gagasangagasan tersebut merupakan hal yang sangat penting pada tahap penyelidikan dalam rangka pembelajaran berbasis masalah. Pada tahap ini mahasiswa memberikan bantuan yang dibutuhkan peserta didik tanpa mengganggu aktifitas peserta didik.

3. Puncak proyek-proyek pembelajaran berbasis masalah adalah penciptaan dan peragaan hasil kerja ${ }^{6}$.

4. Mengembangkan dan menyajikan hasil kerja Hasil-hasil yang telah diperoleh harus dipresentasikan sesuai pemahaman peserta didik. Peserta didik secara mandiri atau kelompok memberikan tanggapan atas hasil kerja temannya. Dalam hal ini mahasiswa mengarahkan, memberi tanggapan atas pendapat-pendapat yang yang diberikan oleh peserta $\operatorname{didik}^{7}$

5. Menganalisis dan mengevaluasi hasil pemecahan masalah

Tugas mahasiswa pada tahap akhir pembelajaran berbasis pemecahan masalah adalah membantu peserta didik menganalisis dan mengevaluasi proses berpikir mereka sendiri, dan keterampilan penyelidikan yang mereka gunakan ${ }^{8}$.

\section{Kelebihan dan Kekurangan Pembelajaran Berbasis}

\section{Masalah}

Kelebihan pembelajaran berbasis masalah antara lain:

a. Peserta didik lebih memahami konsep yang diajarkan sebab mereka sendiri yang menemukan konsep tersebut.

b. Melibatkan secara aktif memecahkan masalah dan menuntut ketrampilan berpikir peserta didik yang lebih tinggi.

c. Pengetahuan tertanam berdasakan skema yang dimiliki peserta didik sehingga pembelajaran lebih bermakna.

d. Peserta didik dapat merasakan manfaat pembelajaran sebab masalah-masalah yang diselesaiakn berkaitan dengan kehidupan nyata.

e. Proses pembelajaran melalui pembelajaran berbasis masalah dapat membiasakan para peserta didik untuk menghadapi dan memecahkan masalah secara terampil. Apabila menghadapi permasalahan dalam kehidupan sehari-hari peserta didik sudah mempunyai kemampuan untuk menyelesaikannya.

\footnotetext{
${ }^{6}$ Trianto, Model Pembelajaran Terpadu (Jakarta : Bumi

Aksara, 2011), h 73-75

${ }^{7}$ Mustaji, Op.cit, h. 77

${ }^{8}$ Trianto, Op.cit, h.75
} 
f. Dapat mengembangkan kemampuan peserta didik untuk berpikir kritis dan mengembangkan kemampuan mereka untuk menyesuaikan dengan pengetahuan baru ${ }^{9}$

Kelemahan pembelajaran berbasis masalah antara lain:

a. Menentukan suatu masalah yang tingkat kesulitanya sesuai dengan tingkat berpikir peserta didik, serta pengetahuan dan pengalaman yang telah dimiliki oleh peserta didik sangat memerlukan ketrampilan dan kemampuan mahasiswa.

b. Proses belajar dengan pembelajaran berbasis masalah membutuhkan waktu yang cukup lama

c. Mengubah kebiasaan peserta didik dari belajar dengan mendengarkan dan menerima informasi dari mahasiswa menjadi belajar dengan banyak berpikir memecahkan masalah merupakan kesulitan tersendiri bagi peserta didik.

B. Problematika Mahasiswa dalam Menulis Karya Ilmiah Pembahasan berikut akan mengurai tentang berbagai problematika yang menjadi kendala mahasiswa dalam menulis karya ilmiah.

\section{Kendala dari dalam diri Mahasiswa (Internal Faktor)}

Bagian ini akan membahas kendala-kendala yang dihadapi mahasiswa yang berkaitan erat dengan dirinya sendiri yang meliputi aspek-aspek utama antara lain: bakat dan motivasi mahasiswa dalam menulis, wawasan mahasiswa yang akan dituangkan dalam bentuk tulisan, dan kendala-kendala yang menyangkut persoalan kemampuan bahasa tertulis mahasiswa.

\section{a. Tidak berbakat}

Menulis merupakan salah satu keterampilan dasar yang dimiliki seseorang, termasuk mahasiswa. Banyak orang yang berpendapat menulis merupakan hal yang mudah. Kalau bisa membaca maka pasti akan bisa menulis. Namun, kenyataan yang tidak dapat dipungkiri bahwa tidak semua orang dapat menghasilkan suatu karya tulis yang layak untuk dipublikasikan. Banyak iantara mahasiswa yang bahkan tidak mampu menghasilkan tulisan ilmiah paling sederhana sekalipun. Sebagai contoh; seorang mahasiswa yang mendapatkan tugas penyusunan makalah atau laporan ilmiah sebagai bahan presentasi harus meminta bantuan orang lain untuk menyelesaikannya. Bahkan, banyak diantara mahasiswa tersebut hanya menciplak tulisan orang lain (plagiat). Selain itu banyak mahasiswa yang harus terkatung-katung tidak mampu menyelesaikan studinya karena terkendala pada penulisan skripsi.

Ketidakberdayaan seorang mahasiswa dalam menciptakan sebuah tulisan ilmiah tidak lepas dari bakat, pemikiran dan kemampuan yang dimilikinya. Aktivitas menulis menuntut adanya penggabungan antara bakat (telenta) seseorang dengan kemapuan serbahasa yang dimilikinya. Merasa kurang berbakat akan menjadi salah satu kendala bagi seseorang sehingga tidak menulis7. Meskipun ada juga pendapat yang mengatakan bahwa menulis tidak ada hubungannya dengan bakat. Lepas dari adanya hubungan atau tidak namun setidaknya seseorang harus mempunyai bakat sekecil apapun untuk dikembangkan sebagai dasar untuk memunculkan kemauan dan motivasi dalam dirinya. Perlu disadari bahwa aktivitas menulis merupakan aktivitas yang membutuhkan proses. Proses tersebut meliputi proses persiapan, penulisan, pengeditan dan penyajian. Proses persiapan tersebut termasuk mengembangkan talenta atau bakat yang ada dalam diri dengan cara berlatih.

Bakat bawaan sejak lahir memerlukan sebuah proses pengembangan agar dapat menghasilkan suatu karya. Kurang berbakat yang menjadi kendala dalam hal ini bukan berarti mahasiswa tidak mampu menulis kata atau kalimat. Namun, kemampuan tersebut tidak cukup untuk menghasilkan karya ilmiah yang layak untuk dipublikasikan. Akibatnya, aktivitas menulis akan menjadi sebuah beban bagi mahasiswa bahkan menjadi sebuah momok yang menakutkan dan harus dihindari.

b. Kurangnya motivasi, sifat malas, tidak percaya diri Segala tindakan yang dilakukan oleh manusia berawal dari niat. Dalam

hal ini, dapat dikatakan bahwa jika seseorang melakukan sesuatu pasti karena ada niat dan karena motivasi untuk melakukannya. Seorang pelajar harus bersungguhsungguh belajar, ikut les, belajar tidak kenal waktu karena termotivasi untuk mendapatkan nilai yang bagus dan memperoleh ilmu pengetahuan. Setiap kegiatan yang dilakukan oleh seseorang tidak lepas dari motivasi yang muncul baik dari dalam dirinya maupun dari orang lain. Demikian halnya dengan kegiatan menulis. seorang penulis harus meluangkan waktu untuk duduk membaca, menggali informasi untuk menemukan ide yang selanjutnya akan diproses untuk menghasilkan tulisan. Proses tersebut dijalani karena adanya motivasi. Motivasi tersebut sangat penting karena akan menjadi motor penggerak dalam kegiatan menulis seperti yang dikatakan oleh Kartanegara bahwa motivasi sangat penting dalam setiap kegiatan termasuk kegiatan menulis. Motivasi akan menjadi pendorong dalam melaksanaan kegiatan menulis ${ }^{10}$.

Ada berbagai alasan yang menjadi motivasi seseorang untuk menulis; 1) ada orang yang menulis hanya karena sebuah keharusan seperti yang banyak dilakukan oleh mahasiswa sekarang ini. Mereka menulis hanya karena tugas dari dosen, karena ingin menyelesaikan studi, bukan karena kesadaran sendiri untuk memperdalam dan mengembangkan ilmunya. 2) Ada yang menulis karena termotivasi untuk membagi dan menyebarkan ilmu kepada orang lain. Penulis dalam kategori ini selain akan mendapatkan manfaat financial dari hasil penjualan hasil karyanya juga akan semakin luas ilmu pengetahuan yang dimilikinya, karena semakin banyak dia menulis maka akan semakin sering dia membaca. Mereka memegang prinsip bahwa "menulislah maka dunia akan mengenalmu" 3) ada yang menulis karena menulis merupakan kegemaran dan menjadi hiburan tersendiri bagi dirinya. Penulis dalam kategori ini akan memanfaatkan setiap waktu luang yang dimilikinya untuk menciptakan karya tulis dalam bentuk apapun dan sesederhana apapun. 4) ada

\footnotetext{
${ }^{9}$ Wina Sanjaya, Op.cit, h.218-219
}

${ }^{10}$ Kartanegara, M., Seni Mengukir Kata: Kiat-Kiat Menulis
Efektif Kreatif. Bandung: Mizan Learning Centre, 2005), h.61. 
yang menulis karena menulis karena termotivasi untuk mendapatkan uang (menulis telah menjadi sumber penghidupannya); artinya jika tidak menghasilkan karya maka tidak dapat memenuhi kebutuhannya.

Rendahnya jumlah karya tulis yang dihasilkan oleh mahasiswa disebabkan karena kurangnya motivasi yang ada dalam diri mereka. Hal tersebut menjadi hambatan yang besar bagi mahasiswa dalam menghasilkan karya tulis terutama karya tulis ilmiah. Mereka tidak mempunyai keinginan kuat untuk mengembangkan sendiri talenta yang dimilikinya. Mahasiswa menulis jika ada tugas dosen atau untuk mendapatkan nilai. Itu merupakan motivasi yang tidak kuat, sehingga dalam prosesnya terkadang mahasiswa hanya menempuh jalan pintas dengan menyalin hasil karya orang lain.

Oleh karena itu hal yang pertama yang harus dilakukan oleh mahasiswa untuk memulai kegiatannya termasuk menulis adalah membangun motivasi dalam diri untuk melakukannya. Dengan adanya motivasi yang kuat dalam diri maka setiap tantangan yang dihadapi akan menjadi mudah. Besar kecilnya hasil karya yang dihasilkan bergantung pada seberapa besar motivasi yang ada dalam diri penulis pada saat akan melakukannya.

c. Kesulitan untuk memulai dan tidak fokus

Banyak mahasiswa yang memiliki keinginan untuk menulis. Keinginan tersebut muncul ketika melihat atau mengangumi hasil karya orang ain. Kekaguman terhadap hasil karya orang lain dapat menjadi pemicu munculnya motivasi dalam dirinya. Sayangnya, keinginan tersebut terkendala pada ketidaktahuan memulai dari mana. Kesulitan untuk memulai sebuah tulisan tidak hanya dialami oleh mahasiswa sebagai penulis pemula namun juga dapat terjadi pada penulis senior. Hambatan yang paling sering dialami oleh penulis pemula, meskipun penulis senior juga mengalaminya adalah kesulitan untuk memulai $^{11}$. Banyaknya permasalahan yang terjadi disekitar kita menjadi penyebab kesulitan untuk memulai tulisan tersebut.

Kesulitan dalam memilih dan menentukan topik, kesulitan dalam meramu ide dan gagasan mengakibatkan seorang penulis merasa tidak tahu harus memulai dari mana.

Tidak hanya kesulitan untuk memulai, banyaknya pengaruh dari luar seperti; banyaknya kegiatan yang bersifat "santai", pengaruh lingkungan, pengaruh hiburan dan lain-lain menyebabkan mahasiswa akan menjadi tidak fokus atau tidak berkonsentrasi. Akibatnya mahasiswa tersebut tidak fokus terhadap apa yang akan dilakukannya seperti tidak fokus dalam menemukan ide, tidak fokus dalam mencari teori pendukung dan tidak fokus dalam menuangkan ide tersebut dalam bentuk tulisan ilmiah.

d. Wawasan yang sempit akibat malas membaca

Membaca dan menulis merupakan bagian dari keterampilan berbahasa yang dimiliki oleh setiap orang. Ibarat dua sisi mata uang kegiatan membaca dan menulis merupakan kegiatan yang harus berjalan beriringan dan saling melengkapi. Seorang penulis yang baik lahir dari membaca yang baik. Artinya dengan membaca memperluas dan mengembangkan wawasan berpikir maka dengan menulis merupakan pengikat dari ilmu pengetahuan yang telah dimiliki.

Membaca merupakan jalan untuk menemukan ide atau pemahaman terhadap sebuah permasalahan. Keinginan untuk menulis akan muncul ketika mendapatkan ide atau gagasan. Selain itu, setiap karya ilmiah yang dihasilkan harus mengandung sebuah kebenaran ilmiah. Kebenaran ilmiah tersebut didasarkan pada bukti, data, teori yang kesemuanya didapatkan dengan membaca. Jadi, membaca merupakan dasar dari kegiatan menulis. sayangnya, di lingkungan mahasiswa tradisi membaca belum terlaksana dengan baik. Akibatnya, kegiatan menulis mengalami hambatan karena wawasan mahasiswa menjadi sempit, kurang kreatif, tidak ada pengalaman. Hal tersebut memunculkan perasaan malas dan tidak termotivasi untuk menulis.

\section{e. Kendala Kebahasaan}

Menulis merupakan suatu bentuk manifestasi keterampilan berbahasa paling akhir dikuasai pelajar bahasa setelah kemampuan mendengarkan/menyimak, berbicara dan membaca. Dibanding tiga kemapuan berbahasa yang lain, kemampuan menulis lebih sulit dikuasai bahkan oleh penutur asli bahasa yang bersangkutan sekalipun. Hal itu disebabkan kemampuan menulis menghendaki penguasaan berbagai unsur kebahasaan dan unsur di luar bahasa itu sendiri yang akan menjadi isi dari sebuah tulisan. Baik unsur kaidah bahasa maupun unsur isi haruslah terjalin sedemikian rupa sehingga menghasilkan sebuah tulisan yang runtut dan padu.

Kendala kebahasaan yang sering dialami oleh mahasiswa dalam melakukan kegiatan menulis adalah kesulitan dalam merangkai kata menjadi kalimat yang efektif. Hal tersebut merupakan kendala besar dalam kegiatan menulis karena isi tulisan ilmiah harus memiliki kesatuan dan keterkaitan antara kalimat yang satu dengan kalimat yang lainnya sehingga pesan yang disampaikan dalam tulisan tersebut dapat diterima dengan baik oleh pembaca.

Kendala kebahasaan yang lainnya adalah terbatasnya perbendaharaan

kata dan istilah yang dimiliki oleh mahasiswa mengenai suatu topik permasalahan yang akan ditulis. Karena kendala tersebut, dalam prosesnya

mahasiswa seringkali harus berhenti menulis karena kehabisan kata/istilah

yang akan dirangkai. Hal tersebut disebabkan karena sempitnya wawasan

yang dimiliki oleh mahasiswa akibat kurang membaca. Itulah alasannya mengapa membaca dan menulis dikatakan sebagai kegiatan yang saling mendukung satu sama lain.

2. Kendala dari luar diri Mahasiswa (Eksternal Faktor)

\footnotetext{
${ }^{11}$ Mawardi, D, Cara Mudah Menulis dengan Metode 12 Pas

(Jakarta: Raih Asa Sukses, 2009), h.31.
} 
Pada bagian ini penulis akan memaparkan hambatan atau kendala ynag dihadapi mahasiswa dalam menulis karya ilmiah yang berkaitan erat dengan aspek-aspek dari luar diri mahasiswa. Pada bagian ini penulis lebih memfokuskan pembahasan pada aspek-aspek yang berkaitan dengan lingkungan belajar mahasiswa. Kecenderungan sikap mahasiswa yang "spoon feed" menuntut permahasiswaan tinggi untuk meningkatkan komitmennya pada seluruh aspek termasuk pengembangan pengajaran karya tulis ilmiah. Perhatian terhadap pengembangan pengajaran karya tulis ilmiah dianggap penting karena hal tersebut menjadi sebuah problematika mahaiswa ketika institusi tidak menunjukkan komitmen yang tinggi dalam menyikapi hal tersebut. Padahal, komitmen institusi akan memberikan pengaruh terhadap pengembagan wawasan mahasiswa sebagai upaya peningkatan jumlah publikasi ilmiah di permahasiswaan tinggi.

a. Tidak adanya pembiasaan sejak dini

Pendidikan seorang anak dimulai dari keluarga, lingkungan belajar dan lingkungan masyarakat. Pembiasaan dalam keluarga umumnya akan terbawa pada lingkungan belajar dan juga lingkungan masyarakat. Hambatan lain yang dihadapi mahasiswa dalam melakukan kegiatan menulis adalah kurangnya pembiasaan sejak dini. Artinya seorang anak yang tidak terbiasa menulis sejak kecil merasa sangat sulit untuk menghasilkan sebuah tulisan meskipun telah duduk di permahasiswaan tinggi.

Mahasiswa yang tidak mendapatkan pembiasaan sejak dini untuk melakukan kegiatan menulis (yang pada umumnya dimulai dengan pembiasaan membaca) akan sulit mengenali kompetensi kebahasaan yang dimilikinya, sehingga cenderung kurang percaya diri dalam menulis. Tidak

hanya itu, secara fisik mahasiswa yang tidak terbiasa menulis akan merasa sulit menemukan ide, tidak mampu menyusun kalimat secara efektif sebagai akibat dari kurang berkembangnya intelektualitas yang dimilikinya. Membiasakan anak untuk menulis pada usia dini dapat pula merangsang intelektualitasnya, khususnya dalam mengembangkan imajinasi dan rasionya ${ }^{12}$.

b. Kurangnya motivasi dari lingkungan belajar

Mengapa kegiatan menulis di permahasiswaan tinggi sangat penting. Jawaban yang paling sederhana adalah karena di permahasiswaan tinggi menulis merupakan "jalan yang wajib dilewati mahasiswa setiap hari”. Ini dapat dimaknai bahwa sebagian besar aktivitas mahasiswa, baik berupa tugas-tugas harian dari dosen, ujian semester, maupun pengisian kelengkapan administrasi, membutuhkan keterampilan menulis. Tanpa kemampuan yang memadai dalam menulis, mahasiswa akan kesulitan untuk mengikuti proses pembelajaran dengan baik, bahkan mungkin tidak akan dapat menyelesaikan studinya.

\footnotetext{
${ }^{12}$ Iswidharmanjaya, D., Bila Anak Usia Dini Bersekolah, (Jakarta: Elex Media, 2006).

${ }^{13}$ House, J. D. The Independent Effects of Student

Characteristics and Instructional Activities on Achievement:
}

Dalam pelaksanaan kegiatan menulis mahasiswa tidak hanya menemui kendala dari dalam dirinya tapi juga dari lingkungannya. Salah satu hambatan tersebut adalah kurangnya motivasi dan penekanan dari dosen. Motivasi seorang dosen kepada mahasiswa sangat besar pengaruhnya terhadap keberhasilan mahasiswa. Jika mahasiswa percaya bahwa pengajarnya mempunyai perhatian terhadapnya maka akan menjadi tambahan alasan untuk belajar. Motivasi merupakan kunci keberhasilan sebuah pengajaran ${ }^{13}$. Sebagai seorang fasilitator, seorang dosen seharusnya bertindak aktif untuk memotivasi mahasiswa dalam berbagai hal termasuk dalam mengembangkan pengetahuan yang dimilkinya dengan cara menulis. Sikap pasif dan rendahnya motivasi dari dosen akan menambah daftar panjang hambatan yang dihadapi mahasiswa dalam menulis.

c. Terbatasnya wadah pelatihan penulisan karya ilmiah Hambatan atau kendala lain yang dihadapi mahasiswa dalam menghasilkan tulisan ilmiah adalah terbatasnya wadah bagi mahasiswa untuk berlatih. Hal tersebut terlihat pada kurangnya kegiatan pelatihan, workshop, maupun lomba yang diadakan di lingkungan permahasiswaan tinggi baik di tingkat jurusan maupun tingkat universitas. Hal tersebut menyebabkan mahasiswa menjadi tidak termotivasi untuk melakukan kegiatan menulis ilmiah. Mahasiswa menganggap bahwa kegiatan menulis ilmiah bukanlah suatu hal yang penting. Akibatnya, banyak mahasiswa yang kesulitan menyelesaikan kuliahnya karena terhambat pada penulisan skripsi. Jalan yang harus ditempuh oleh mahasiswa tersebut adalah meminta bantuan orang lain. Ironisnya lagi, sering ditemukan mahasiswa hanya menyalin skripsi orang lain dengan memberikan sedikit perubahan pada waktu dan tempat penelitian. Dalam hal ini tentu saja institusi memberikan andil dalam membangun "ketidakberdayaan" mahasiswa dalam menghasilkan karya ilmiah yang murni dan layak untuk dipublikasikan.

d. Kurikulum tidak mencakup penulisan karya ilmiah secara menyeluruh

Pengajaran penulisan karya ilmiah di permahasiswaan tinggi (kecuali jurusan tertentu) tidak tersentuh secara keseluruhan oleh kurikulum. Artinya, penulisan karya ilmiah tersebut memiliki porsi yang sangat kecil dalam kurikulum tidak menjadi sebuah mata kuliah wajib dengan bobot tertentu dan harus dilulusi oleh mahasiswa. Bahkan, ada beberapa jurusan yang tidak memasukkan penulisan karya ilmiah dalam kurikulumnya. Akibatnya, mahasiswa harus belajar sendiri untuk menulis tanpa ada petunjuk, pendamping atau fasilitator. Hasilnya, kita bisa bertanya selain sekripsi, karya ilmiah apa yang berhasil dipublikasikan

An Application of the Input-Environment Outcomes Assessment Model (International Journal of Instructional Media, 29(2), 225-239, 2002) 
mahasiswa di setiap jurusan atau fakultas setiap tahunnya.

e. Tidak tersedianya waktu khusus untuk pelatihan/ pengembangan karya ilmiah

Kendala lain adalah tidak tersedianya waktu khusus untuk pelatihan/pengembangan kemampuan mahasiswa dalam menulis karya ilmiah.

Hal tersebut sebenarnya tidak terlepas dari kurikulum sebuah universitas.

Tidak tersedianya kegiatan ekstrakurikuler yang secara spesifik memberikan

pelatihan karya ilmiah menciptakan ruang yang makin sempit bagi mahasiswa untuk berlatih sehingga mahasiswa kurang mendapatkan kesempatan untuk mengembangkan bakat menulis yang dimilikinya.

f. Kurangnya dukungan financial

Untuk memulai sebuah tulisan karya ilmiah, seorang penulis juga harus mempunyai beberapa persiapan. Persiapan tersebut diantaranya keinginan atau motivasi untuk menulis, kemampuan untuk menulis, pemahaman terhadap topik yang akan ditulis, referensi yang cukup, ketersediaan waktu untuk menulis dan sebagainya. Jika hal tersebut telah dipenuhi maka seorang penulis telah siap untuk memulai sebuah tulisan ilmiah.

Bagi seorang mahasiswa, keberhasilan kegiatan yang dilakukannya masih bergantung pada seberapa besar dukungan lingkungan terhadap dirinya. Dalam kegiatan menulis ilmiah, penyediaan sarana seperti ruang pelatihan, mentoring, kelengkapan referensi, pemberian award merupakan salah satu bentuk dukungan tersebut. Untuk mewujudkan dukungan tersebut diperlukan ketersediaan dana yang cukup. Tidak tersedianya alokasi dana untuk kegiatan tersebut mengakibatkan fasilitas pendukung tidak dapat terpenuhi. Dengan demikian, mahasiswa merasa terkendala karena tidak mampu melakukannya secara mandiri tanpa dukungan dari lingkungan sekitarnya.

\section{Upaya Meningkatkan kemampuan menulis karya} ilmiah

Untuk mengatasi berbagai persoalan menulis yang dihadapi mahasiswa, nampaknya pihak lembaga pendidikan tidak bisa berpangku tangan. Setiap stakeholder mungkin saja selama ini telah berhasil secara kuantitatif memotivasi mahasiswa menulis yang digunakan untuk mengumpulkan angka kredit. Oleh karena itu untuk memecahkan persoalannya. seyogianya diarahkan kepada upaya peningkatan kemampuan menulis dan kualitas karya tulis ilmiah.

Pertama, perlu dibentuk tim pembimbing penulisan karya ilmiah yang bertugas untuk memeriksa, meluruskan, dan mematangkan materi yang ditulis oleh mahpeserta didik. Mahasiswa akan dibimbing secara teknis, isi, dan penggunaan bahasa. Tim pembimbing terdiri dari pihak manajemen permahasiswaan tinggi dan mahasiswa-mahasiswa senior yang mengerti tentang penulisan karya ilmiah, serta pihak-pihak lain di permahasiswaan tinggi yang dianggap mampu mengemban tugas tersebut.

Kedua, perlu dibentuk Forum Pengkajian Karya Tulis Ilmiah Mahasiswa di setiap permahasiswaan tinggi. Forum ini bertugas untuk mengkaji dan mendiskusikan kelayakan materi prapembimbingan dan pascapembimbingan (setelah karya tulis ilmiah selesai dikerjakan).

Ketiga, perlu dilakukan presentasi karya tulis ilmiah sebelum dikirimkan kepada Tim penilai karya tulis Mahasiswa. Presentasi dilakukan di hadapan Tim Pembimbing, Forum Pengkajian Karya Tulis Ilmiah Mahasiswa, dan dihadiri oleh mahasiswa-mahasiswa sejawat.

Untuk tertibnya proses pelaksanaan akan disusun alur kegiatan yang berorientasi kepada peningkatan kualitas. Alur kerja yang diusulkan adalah sebagai berikut :

Usulan Alur Kegiatan Penulisan Karya Ilmiah Mahasiswa (Penelitian, Penulisan Buku, dan Makalah)

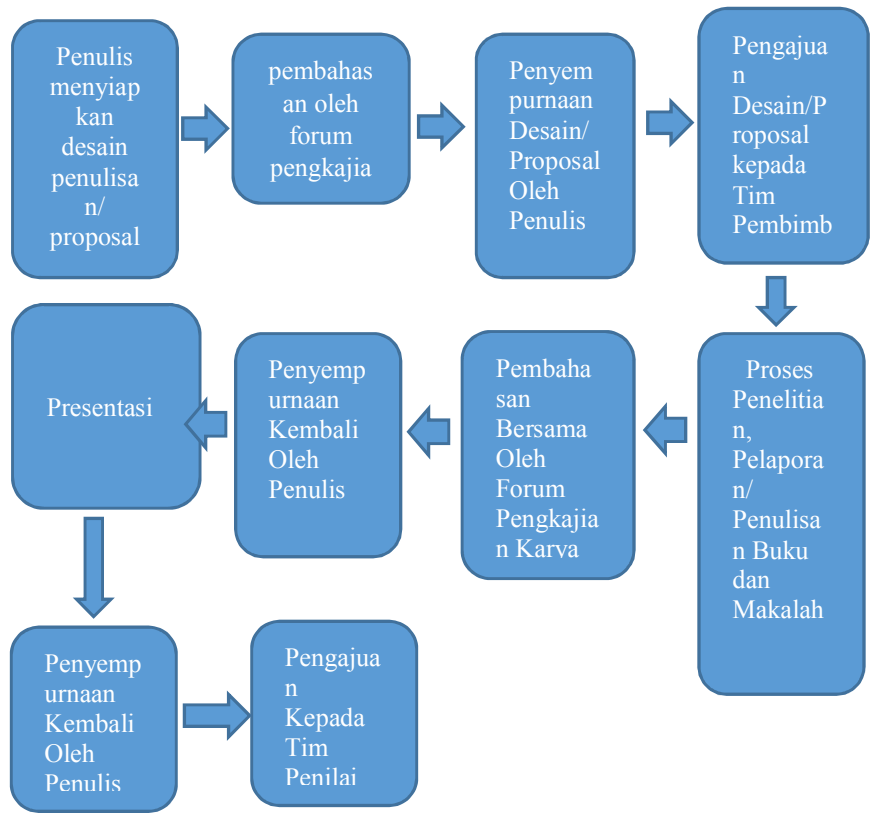

Gambar 1 Usulan Alur Kegiatan Penulisan Karya Ilmiah Mahasiswa

Keempat, perlu diintensifkan lomba penulisan karya tulis ilmiah di lingkungan internal permahasiswaan tinggi dengan pemberian penghargaan yang menarik bagi juara. Penghargaan yang dimaksudkan tidak hanya berupa pemberian piagam atau hadiah barang, tetapi juga penghargaan dalam bentuk lain seperti kesempatan mengikuti lomba pada tingkat yang lebih tinggi, penghargaan terhadap karier, mengikuti pelatihan, atau diberikannya kesempatan sebagai anggota Tim Pembimbing Penulisan Karya Ilmiah mahasiswa (kalau ada).

Kelima, perlu dilakukan workshop penulisan karya ilmiah atau ceramah secara priodik di setiap perguruan tinggi dengan mengundang penulis-penulis yang handal atau para kolumnis di media massa. Terutama untuk penulisan di media massa, tentunya menimba pengalaman dari para kolumnis sangat perlu.

Keenam, perlu dilakukan pembenahan dan penyempurnaan sarana sumber informasi di permahasiswaan tinggi. Bagaimanapun tanpa ditunjang oleh informasi mahasiswa akan kesulitan dalam menulis. Sarana informasi 
yang perlu diperhatikan adalah perpustakaan dan fasilitas internet.

Mudah-mudahan dengan memperhatikan dan melaksanakan hal-hal yang telah dikemukakan di atas kemampuan mahasiswa dalam menulis dan kualitas karya tulis ilmiah mahasiswa dapat meningkat. Untuk itu sangat diharapkan adanya perhatian serius dari berbagai pihak terutama dari kepala perguruan tinggi dalam perannya sebagai motivator dan fasilitator. Demikian juga halnya mahasiswa sebagai faktor kunci kiranya perlu mengubah pandangan dan sikap dengan menempatkan kegiatan menulis sebagai salah satu kegiatan penting dalam profesinya. Bagaimanapun fakta kegagalan dalam menulis karya ilmiah mestinya cukup memberikan pelajaran yang berharga bagi mahasiswa bahwa kegiatan menulis tidak bisa dianggap sepele. Dalam hal ini kita harapkan supaya mahasiswa mampu bersikap dan bertindak profesional sehingga tidak tersandung pada batu yang sama untuk kedua kali.

3. Langkah - Langkah Pembelajaran Metode
Pembelajaran Berbasis Masalah

Tabel 1

\begin{tabular}{|c|c|c|}
\hline $\begin{array}{l}\text { Tahap } \\
\text { Pembelajaran }\end{array}$ & $\begin{array}{l}\text { Kegiatan } \\
\text { Pengajar }\end{array}$ & $\begin{array}{l}\text { Kegiatan } \\
\text { didik }\end{array}$ \\
\hline \multirow[t]{2}{*}{$\begin{array}{l}\text { Menemukan } \\
\text { masalah }\end{array}$} & $\begin{array}{l}\text { Memberikan } \\
\text { permasalahan } \\
\text { yang diangkat } \\
\text { dari latar } \\
\text { kehidupan } \\
\text { sehari-hari }\end{array}$ & $\begin{array}{l}\text { Berusaha menemukan } \\
\text { permasalahan dengan } \\
\text { cara melakukan } \\
\text { kajian dan analisis } \\
\text { secara } \\
\text { terhadap cermat } \\
\text { permasalahan yang } \\
\text { diberikan }\end{array}$ \\
\hline & $\begin{array}{l}\text { Memberikan } \\
\text { sedikit fakta di } \\
\text { seputar konteks } \\
\text { permasalahan }\end{array}$ & $\begin{array}{l}\text { Melakukan analisis } \\
\text { terhadap fakta } \\
\text { sebagai dasar dalam } \\
\text { menemukan masalah }\end{array}$ \\
\hline \multirow[t]{2}{*}{$\begin{array}{l}\text { Mendefinisikan } \\
\text { masalah }\end{array}$} & $\begin{array}{l}\text { Mendorong dan } \\
\text { membimbing } \\
\text { peserta didik } \\
\text { untuk } \\
\text { menggunakan } \\
\text { kecerdasan } \\
\text { intrapersonal } \\
\text { dan kemampuan } \\
\text { awal (prior } \\
\text { knowledge) }\end{array}$ & $\begin{array}{l}\text { Dengan } \\
\text { menggunakan } \\
\text { kecerdasan } \\
\text { intrapersonal dan } \\
\text { kemampuan awal } \\
\text { (prior } \\
\text { knowledge)berusaha } \\
\text { memahami masalah }\end{array}$ \\
\hline & $\begin{array}{l}\text { Membimbing } \\
\text { peserta didik } \\
\text { secara bertahap } \\
\text { untuk } \\
\text { mendefinisikan } \\
\text { masalah }\end{array}$ & $\begin{array}{l}\text { Berusaha } \\
\text { mendefinisikan } \\
\text { permasalahan dengan } \\
\text { menggunakan } \\
\text { parameter yang jelas }\end{array}$ \\
\hline $\begin{array}{l}\text { Mengumpulkan } \\
\text { Fakta }\end{array}$ & $\begin{array}{l}\text { Membimbing } \\
\text { peserta didik } \\
\text { untuk } \\
\text { melakukan } \\
\text { pengumpulan } \\
\text { data }\end{array}$ & $\begin{array}{l}\text { Melakukan } \\
\text { pengumpulan data } \\
\text { dengan menggunakan } \\
\text { pengalaman- } \\
\text { pengalaman yang } \\
\text { sudah diperolehnya }\end{array}$ \\
\hline
\end{tabular}

\begin{tabular}{|c|c|c|}
\hline & $\begin{array}{l}\text { Membimbing } \\
\text { peserta didik } \\
\text { melakukan } \\
\text { pencarian } \\
\text { informasi } \\
\text { dengan berbagai } \\
\text { cara/metode }\end{array}$ & $\begin{array}{l}\text { Melakukan pencarian } \\
\text { informasi dengan } \\
\text { berbagai cara serta } \\
\text { dengan menggunakan } \\
\text { keceedasan majemuk } \\
\text { yang dimiliki }\end{array}$ \\
\hline & $\begin{array}{l}\text { Membimbing } \\
\text { peserta didik } \\
\text { melakukan } \\
\text { pengelolaan } \\
\text { informasi }\end{array}$ & $\begin{array}{l}\text { Melakukan } \\
\text { pengelolaan/pengatur } \\
\text { an informasi } \\
\text { (information } \\
\text { management) yang } \\
\text { telah diperoleh, } \\
\text { dengan berpatokan } \\
\text { pada: } \\
\text { Know, yaitu } \\
\text { informasi apa yang } \\
\text { diketahui } \\
\text { b. Need to know, } \\
\text { yaitu informasi } \\
\text { apayang dibutuhkan } \\
\text { Need to do, yaitu } \\
\text { informasi apa yang } \\
\text { akan dilakukan } \\
\text { dengan informasi } \\
\text { yang ada }\end{array}$ \\
\hline \multirow[t]{4}{*}{$\begin{array}{l}\text { Menyusun } \\
\text { hipotesis } \\
\text { (dugaan } \\
\text { sementara }\end{array}$} & $\begin{array}{l}\text { Membimbing } \\
\text { peserta didik } \\
\text { untuk meyusun } \\
\text { jawaban/hipotes } \\
\text { is terhadap } \\
\text { permasahan } \\
\text { yang dihadapi }\end{array}$ & $\begin{array}{l}\text { Membuat hubungan } \\
\text { antar berbagai fakta } \\
\text { yang ada }\end{array}$ \\
\hline & $\begin{array}{l}\text { Membimbing } \\
\text { peserta didik } \\
\text { untuk } \\
\text { menggunakan } \\
\text { kecerdasan } \\
\text { majemuk dalam } \\
\text { menyusun } \\
\text { hipotesis }\end{array}$ & $\begin{array}{l}\text { Menggunakan } \\
\text { berbagai kecerdasan } \\
\text { majemuk untuk } \\
\text { meyusun hipotesis }\end{array}$ \\
\hline & $\begin{array}{l}\text { Membimbing } \\
\text { peserta didik } \\
\text { untuk } \\
\text { menggunakan } \\
\text { kecerdasan } \\
\text { interpersonal } \\
\text { dalam } \\
\text { mengungkapka } \\
\text { n pemikirannya }\end{array}$ & $\begin{array}{l}\text { Menggunakan } \\
\text { berbagai kecerdasan } \\
\text { interpersonal untuk } \\
\text { mengungkapkan } \\
\text { pemikirannya }\end{array}$ \\
\hline & $\begin{array}{l}\text { Membimbing } \\
\text { peserta didik } \\
\text { untuk meyusun } \\
\text { alternative } \\
\text { jawaban } \\
\text { sementara }\end{array}$ & $\begin{array}{lr}\text { Berusaha } & \text { menyusun } \\
\text { beberapa } & \text { jawaban } \\
\text { sementara } & \end{array}$ \\
\hline $\begin{array}{l}\text { Melakukan } \\
\text { penyelidikan }\end{array}$ & $\begin{array}{l}\text { Membimbing } \\
\text { peserta didik } \\
\text { untuk }\end{array}$ & $\begin{array}{l}\text { Melakukan } \\
\text { penyelidikan terhadap }\end{array}$ \\
\hline
\end{tabular}




\begin{tabular}{|c|c|c|}
\hline & $\begin{array}{l}\text { melakukan } \\
\text { penyelidikan } \\
\text { terhadap } \\
\text { informasi dan } \\
\text { data yang telah } \\
\text { diperolehnya }\end{array}$ & $\begin{array}{l}\text { data dan informasi } \\
\text { yang telah diperoleh }\end{array}$ \\
\hline & $\begin{array}{l}\text { Dalam } \\
\text { membimbing } \\
\text { peserta didik } \\
\text { melakukan } \\
\text { penyelidikan, } \\
\text { mahasiswa } \\
\text { membuat } \\
\text { struktur belajar } \\
\text { yang } \\
\text { memungkinkan } \\
\text { peserta didik } \\
\text { dapat } \\
\text { menggunakan } \\
\text { berbagai cara } \\
\text { untuk } \\
\text { mengetahui an } \\
\text { memahami } \\
\text { dunianya }\end{array}$ & $\begin{array}{l}\text { Dalam melakukan } \\
\text { penyelidikan peserta } \\
\text { didik menggunakan } \\
\text { kecerdasan majemuk } \\
\text { yang dimilikinya } \\
\text { untuk memahami dan } \\
\text { memberi makna data } \\
\text { dan informasi yang } \\
\text { ada }\end{array}$ \\
\hline $\begin{array}{l}\text { Menyempurnak } \\
\text { an permasalahan } \\
\text { yang telah } \\
\text { didefinisikan }\end{array}$ & $\begin{array}{l}\text { Membimbing } \\
\text { peserta didik } \\
\text { melakukan } \\
\text { penyempurnaan } \\
\text { terhadap } \\
\text { masalah yang } \\
\text { telah } \\
\text { didefinisikan }\end{array}$ & $\begin{array}{l}\text { Melakukan } \\
\text { penyempurnaan } \\
\text { masalah yang telah } \\
\text { dirumuskan }\end{array}$ \\
\hline $\begin{array}{l}\text { Menyimpulkan } \\
\text { alternatif } \\
\text { pemecahan } \\
\text { masalah secara } \\
\text { kolaboratif }\end{array}$ & $\begin{array}{l}\text { Membimbing } \\
\text { peserta didik } \\
\text { untuk } \\
\text { menyimpulkan } \\
\text { alternatif } \\
\text { pemecahan } \\
\text { secara } \\
\text { kolaboratif }\end{array}$ & $\begin{array}{l}\text { Membuat kesimpulan } \\
\text { alternatif pemecahan } \\
\text { masalah secara } \\
\text { kolaboratif }\end{array}$ \\
\hline $\begin{array}{l}\text { Melakukan } \\
\text { pengujian hasil } \\
\text { (solusi) } \\
\text { pemecahan } \\
\text { masalah }\end{array}$ & $\begin{array}{l}\text { Membimbing } \\
\text { peserta didik } \\
\text { melakukan } \\
\text { pengujian hasil } \\
\text { (solusi) } \\
\text { pemecahan } \\
\text { masalah }\end{array}$ & $\begin{array}{l}\text { Melakukan pengujian } \\
\text { hasil (solusi) } \\
\text { pemecahan masalah. }\end{array}$ \\
\hline
\end{tabular}

4. Penerapan Metode Problem Based Learning untuk Meningkatkan Kemampuan Menulis Karya Ilmiah

Pembelajaran di kelas merupakan tindakan konkret yang dilakukan setelah melewati tahap perencanan dan persiapan yang matang. Metode pembelajaran yang hanya berupa pola dan langkah-langkah harus dilaksanakan secara komunikatif dan menyenangkan agar peserta didik termotivasi dan semangat dalam mengikuti pembelajaran. Oleh karena itu, Pengajar/dosen harus menyusun langkah-langkah teknis dan mendetail sebelum memasuki kegiatan pembelajaran.

Metode pembelajaran berbasis masalah terdiri atas 8 tahap yaitu menemukan masalah, mendefinisikan masalah, mengumpulkan fakta, menyusun hipotesis,melakukan penyelidikan, menyempurnakan permasalahan yang telah didefinisikan, menyimpulkan alternatif pemecahan masalah secara kolaboratif, dan melakukan pengujian hasil (solusi) pemecahan masalah. Untuk mempermudah penerapan model tersebut di kelas maka penerapan model tersebut dalam pembelajaran akan disederhanakan menjadi 6 tahap yaitu (1) menemukan masalah, (2) mendefinisikan masalah, (3) mengumpulkan fakta, (4) menyusun hipotesis, (5) melakukan penyelidikan, mengolah dan menganalis data, dan (6) menguji hasil (solusi) pemecahan masalah.

Penerapan metode pembelajaran berbasis masalah dalam pembelajaran menulis karya tulis ilmiah di kelas dibagi dalam tiga tahap yaitu (1) tahap persiapan, (2) tahap penulisan makalah, dan (3) tahap perbaikan.

a. Persiapan

Pada langkah awal pembelajaran siswa diberi motivasi pentingnya menulis karya tulis ilmiah dalam hal ini adalah menulis makalah hasil pengamatan. pengajar/dosen harus meyakinkaan siswa bahwa menulis karya ilmiah tidak sesulit yang dibayangkan. Langkah kedua, guru memberikan contoh masalah-masalah yang menarik untuk diteliti. Masalah yang dicontohkan adalah masalah sederhana yang banyak dijumpai di masyarakat. Setelah itu, guru meminta siswa untuk membentuk beberapa kelompok. Masing-masing kelompok berdiskusi untuk menemukan permasalahan dengan cara melakukan analisis secara cermat terhadap permasalahan yang diberikan (penerapan tahap 1).

Langkah ketiga siswa berdiskusi untuk memahami topik dan memfokuskan masalah yang hendak diteliti dengan parameter yang jelas (penerapan tahap 2) Langkah yang keempat guru membimbing siswa melakukan pengumpulan fakta dengan menggunakan pengalamanpengalaman yang sudah diperolehnya, melakukan pencarian informasi dengan berbagai cara/metode, melakukan pengelolaan/pengaturan informasi yang telah diperoleh dengan berpatokan pada tiga aspek yaitu informasi apa yang diketahui, informasi apa yang dibutuhkan, dan apa yang dilakukan dengan informasi yang ada (penerapan tahap 3).

Langkah kelima siswa menghubungkan antara pengetahuan sebelumnya dengan fakta yang diperoleh untuk membuat hipotesis/ dugaan sementara (penerapan tahap 4).

Langkah keenam siswa melakukan penyelidikan terhadap data dan fakta yang telah diperoleh di luar kelas. Dalam melakukan penyelidikan siswa menggunakan kecerdasan majemuk yang dimilikinya untuk memahami dan memberi makna data dan informasi yang. Proses ini siswa berlatih untuk bekerja sama dalam sebuah tim. Kemudian memberikan masukan hal-hal yang harus dilakukan (penerapan tahap 5).

b. Langkah Penulisan

Dari data y ang telah dikumpulkan dan dianalisis, mahasiswa menuliskan hasil penyelidikan ke dalam bentuk makalah secara kelompok (penerapan tahap 5) sistematika dan teknik penulisannya berpedoaman pada karya tulis ilmiah yang telah disusun pengajar/dosen dan dijelaskan ketika proses pembelajaran. 
c. Tahap Perbaikan

Pengajar/dosen mengoreksi hasil tulisan siswa, memberi masukan dan diserahkan kembali ke siswa untuk diperbaiki (penerapan tahap 6).

\section{Kerangka Berpikir}

Menulis merupakan keterampilan yang paling sulit jika dibandingkan dengan keterampilan berbahasa lainnya. Menulis membutuhkan pengetahuan menggabungkan pengetahuan intelektual dan berpikir logis yang kemudian dilanjutkan dengan pemilihan bahasa yang efektif dan komunikatif untuk diungkapkan dalam bentuk tulisan. Menulis karya ilmiah merupakan. salah satu kompetensi dasar yang harus dikuasi oleh mahasiswa. Pada jenjang tersebut mahasiswa sudah mampu menulis karya tulis ilmiah dari hasil pengamatan atau penelitian. Namun, faktanya harapan tersebut belum tercapai secara maksimal.

Berdasarkan permasalahan tersebut, diperlukan cara yang tepat untuk memperbaiki kondisi tersebut. Dalam hal ini, peneliti memberikan solusi alternatif yaitu dengan menggunakan Metode pembelajaran berbasis masalah. Dengan demikian diharapkan dalam setiap siklus terjadi peningkatan keterampilan menulis karaya ilmiah.

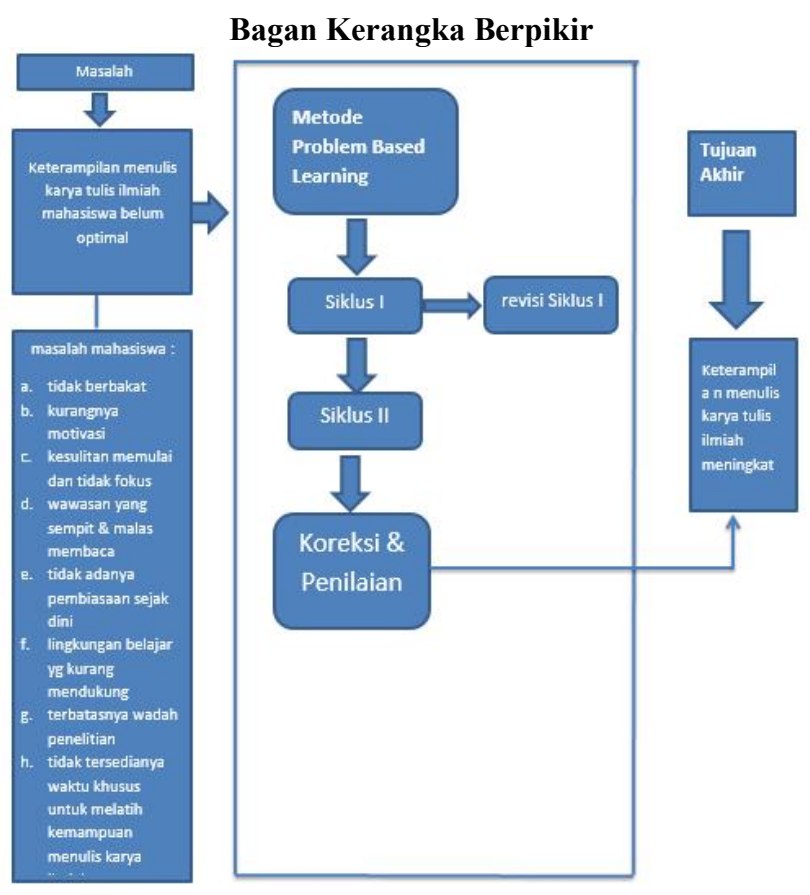

Gambar 2. Kerangka Berfikir

\section{PENUTUP}

\section{A. Kesimpulan}

Berdasarkan hasil pembahasan dapat diambil simpulan sebagai berikut :
1. Rendahnya jumlah karya ilmiah yang dihasilkan disebabkan karena adanya berbagai problematika yang dihadapi mahasiswa dalam menulis karya ilmiah.

2. Problematika yang dihadapi berasal dari diri mahasiswa yaitu kurang berbakat, tidak adanya motivasi, kesulitan dalam memulai, wawasan yang sempit, dan kendala kebahasaan.

3. Pembelajaran berbasis masalah dikembangkan untuk membantu peserta didik mengembangkan kemampuan berpikir, mengembangkan kemampuan memecahan masalah, keterampilan intelektual, dan menjadi peserta didik yang mandiri.

4. Metode pembelajaran berbasis masalah terdiri atas 8 tahap yaitu menemukan masalah, mendefinisikan masalah, mengumpulkan fakta, menyusun hipotesis,melakukan penyelidikan, menyempurnakan permasalahan yang telah didefinisikan, menyimpulkan alternatif pemecahan masalah secara kolaboratif, dan melakukan pengujian hasil (solusi) pemecahan masalah.

5. Untuk mengatasi berbagai persoalan menulis yang dihadapi mahasiswa, nampaknya pihak lembaga pendidikan tidak bisa berpangku tangan. Setiap stakeholder mungkin saja selama ini telah berhasil secara kuantitatif memotivasi mahasiswa menulis yang digunakan untuk mengumpulkan angka kredit. Oleh karena itu untuk memecahkan persoalannya. seyogianya diarahkan kepada upaya peningkatan kemampuan menulis dan kualitas karya tulis ilmiah.

\section{B. Saran}

Berdasarkan hasil pembahasan di atas saran yang direkomendasikan adalah :

1. Bagi mahasiswa dapat menggunakan metode pembelajaran berbasis masalah dengan cara memadukan metode pembelajaran berbasis masalah dengan media yang lain atau sebaliknya memadukan media pembelajaran dengan metode yang lain sesuai dengan kebutuhan. Syarat bagi mahasiswa untuk menggunakan metode pembelajaran berbasis masalah adalah (1) mahasiswa harus diberikan masalah-masalah yang benar-benar menantang dan sedang aktual karena kalau tidak mahasiswa tidak akan termotivasi untuk membuat karya tulis ilmiah, (2) pengajar harus benar-benar membimbing mahasiswa secara intensif dalam menentukan topik dan rumusan masalah sehingga makalah yang disusun sistematis sesuai dengan topik dan rumusan masalah, (3) bahan ajar mahasiswa harus disusun secara sistematis dengan materi yang mendukung, menarik, dan up to date sehingga mahasiswa tertarik untuk membaca, dan (4) sebaiknya tugas untuk mahasiswa ditulis tangan untuk meminimalisir mahasiswa tidak mengerjakan sendiri.

2. Bagi mahasiswa, sebaiknya aktif mengikuti kegiatan pembelajaran dan selalu berlatih menulis terutama menulis karya tulis ilmiah.

3. Bagi peneliti sebaiknya ada penelitian lanjutan dari penelitian ini untuk mengemłangkan metode pembelajaran berbasis masalah sehingga menghasilkan metode yang lebih sempurna. 


\section{REFERENSI}

Direktorat Jenderal Pendidikan Tinggi, Presentasi Sosialisasi Kebijakan Publikasi Ilmiah Pada Mahasiswa dari www.dikti.go.id

Brotowidjoyo, M. D. (1985). Penulisan Karangan Ilmiah. Jakarta: Akademika Pressindo.

Arends, I. Ricard. (2008). Learning To Teach “Belajar Untuk Mengajar”. Yogyakarta: Pustaka Pelajar.

Nur, Mohamad. (2008). Model Pembelajaran Berdasakan Masalah. Surabaya : Pusat Sains dan Matematika Perguruan tinggi Departemen Pendidikan Universitas Negeri Surabaya.

Sudjana, Nana dan Rivai, Ahmad. (2005). Media Pengajaran. Jakarta : Algesindo.

Hasibuan, J.J. dan Mujiono. (2004). Proses Belajar

Mengajar. Bandung: PT. Remaja Rosdakarya

Surakhmad, Winarno. (2002). Pengantar Interaksi Belajar Mengajar. Bandung: Tarsito.

Sanjaya, Wina. (2006). Strategi Pembelajaran. Jakarta: Prenada Media Group.

Ibrahim, H. Muslimin. (2000). Pembelajaran Kooperatif. Surabaya : UNESA UNIVERSITY

Mustaji. (2009). Pengembangan Model Pembelajaran Berbasis Masalah dengan Pola Kolaborasi dalam Mata Kuliah Masalah Sosial. Disertasi. Malang: Program Pascasarjana UIniversitas Negeri Malang.

Trianto. (2011). Model Pembelajaran Terpadu. Jakarta: Bumi Aksara.

M, Kartanegara. (2005). Seni Mengukir Kata: Kiat-Kiat Menulis Efektif Kreatif. Bandung: Mizan Learning Centre.

D, Mawardi. (2009). Cara Mudah Menulis dengan Metode 12 Pas. Jakarta: Raih Asa Sukses.

D, Iswidharmanjaya. (2006). Bila Anak Usia Dini Bersekolah. Jakarta: Elex Media.

D, J. House. (2002). The Independent Effects of Student Characteristics and Instructional Activities on Achievement: An Application of the Input-Environment Outcomes Assessment Model International Journal of Instructional Media. 